\title{
Book Note
}

\section{The Undeniable Politics of Labor Law}

Broken Promise: The Subversion of U.S. Labor Relations Policy: 1947-1994. By James A. Gross.' Philadelphia: Temple University Press, 1995. Pp. xiii, 404. $\$ 49.95$.

Before Congress passed the Wagner Act in 1935. labor untons were confronted with a host of obstacles when attempting to organize and bargain collectively. Employers routinely fired employees attempting to unionize. required workers to sign "yellow dog" contracts conditioning employment upon the promise never to join a union, and circulated "black lists" of pro-union workers to other employers.' As a result of these tactics, employees and unions responded with more aggressive organizing campaigns and strike tactics. More importantly, labor unions took political action and vigorously pushed for protective labor legislation. 2 The result was the Wagner Act, which protected employees' right to organize and explicitly advocaled collective bargaining between unionized employees and their employer." The Acl outlawed employer "unfair labor practices" (ULPS) and crealed the National Labor Relations Board (NLRB) as an enforcement mechanism."

Despite the existence of the National Labor Relations Act (NLRA)," some critics have argued that the Act offers little actual protection." In recent years,

* Professor of Industrial \& Labor Relatuons. Comell Unuresily

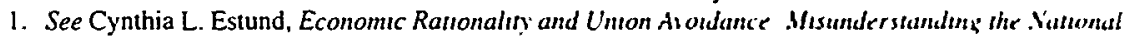
Labor Relations Acr, 71 TEX. L. REV. 921.965 n.169 (1993). Marh D Mendith. Frem Danutnis Halls tor Hiring Halls: Actors Equn and the Closed Shop Dilemma. 96 COLA I L RES 178, 19; \& n $76+1 \% 96$,

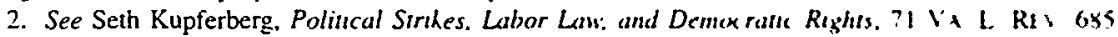
721 (1985) ("During the 1930s, even more than in earlier decades. unons also entered musnsursm polttusal debates and partisan campargns.").

3. See 29 U.S.C. $\$ 151$ (1994).

4. See id. $\S 158(\mathrm{a})$.

5. See id. $\S \S 153-56$.

6. The NLRA includes the Wagner $A c t$ and subsequent anendments See $1 d \$ \$ \$ 1-64$

7. Former AFL-CIO President Lane Kirkland has so frusirated at the Reagan dumunistration's implementation of the NLRA that he was "seriously considenng" calling for ts repeal and opined that labor "may be better off with the law of the jungle" Cathy Trost \& Leonard M Aprar. AFL CIO) (huet Culls

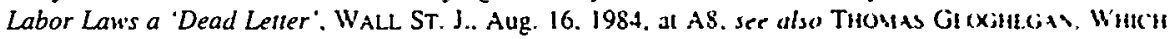
SIDE ARE YOU ON? 252-56 (1991) (arguing that NLRA is "fatally "cash") 
employers have more frequently committed unfair labor practices, hired legal consultants for advice on preventing unionization, and permanently replaced striking workers. ${ }^{8}$ As a result, only ten percent of private sector American workers are unionized-down from thirty-three percent fifty years ago. ${ }^{9}$ An important factor exacerbating this decline has been labor's inability to achieve any meaningful legislative success since 1935 . Labor's recognition of its own political woes has recently caused a shake-up in the leadership of the American Federation of Labor-Congress of Industrial Organizations (AFL-CIO). In 1995, John Sweeney became president of the AFL-CIO after defeating Thomas Donahue, the hand-picked successor of former president Lane Kirkland. ${ }^{10}$ Sweeney's platform included an aggressive political campaign emphasizing the need to train campaign managers and spend thirty-five million dollars in the 1996 elections to support prolabor candidates."

In Broken Promise, James Gross attempts to explain the politics that precipitated the labor movement's decline. He takes aim at labor's biggest political failure to date-the 1947 Taft-Hartley Amendment to the Wagner Act-and accuses it of creating a conflict within the basic philosophy of the NLRA (pp. 215, 272). While the Wagner Act called for a government policy that affirmatively supported collective bargaining, ${ }^{12}$ Taft-Hartley espoused the concept of government neutrality toward collective bargaining. ${ }^{13}$ According to Gross, this inconsistency reduced American labor policy to "shambles in part because its meaning seems to depend primarily on which political party won the last election" (p. 275).

8. See Jack J. Canzoneri, Management's Attitudes and the Need for the Workplace Fairness Act, 41 BuFf. L. Rev. 205, 241-42 (1993); Michael H. LeRoy, Regulating Employer Use of Permanem Striker Replacements: Empirical Analysis of NLRA and RLA Strikes 1935-1991, 16 BERKELEY J. EMP. \& LAB. L. 169, 190-91 (1995); Paul C. Weiler, Promises to Keep: Securing Workers' Rights to Self-Organization Under the NLRA, 96 HARV. L. REv. 1769, 1776-81 (1983); Note, The Liability of Labor Relations Consultants for Advising Unfair Labor Practices, 97 HARV. L. REV. 529 (1983).

9. See Frank Swoboda \& Martha M. Hamilton, Labor Looks to Grow from the Grass Roots. WASH. POST, Feb. 18, 1996, at $\mathrm{HI}$.

10. See id.; What's News, WaLl. ST. J., Oct. 26, 1995, at Al.

11. See Asra Q. Nomani \& Robert L. Rose, Sweeney Slate Focuses on Recruiting, Organization in AFL-CIO Campaign, WALL ST. J., June 29, 1995, at B4; Frank Swoboda \& Thomas B. Edsall, $A F L-C I O$ Endorses Clinton, Approves \$35 Million Political Program, WASH. Post, Mar. 26, 1996, at A6: Swoboda \& Hamilton, supra note 9.

12. See 29 U.S.C. $\S 151$ (1994) ("It is hereby declared to be the policy of the United States to eliminate [obstruction of commerce] . . . by encouraging the practice and procedure of collective bargaining and by protecting the exercise by workers of full freedom of association, self-organization, and designation of representatives of their own choosing .....").

13. See $i d . \S 157$ ("Employees ... shall also have the right to refrain from any or all of such [concerted] activities . ....); id. $\S 158($ b) (defining union unfair labor practices); $i d . \S 158(\mathrm{c})$ (protecting employee right of free speech). 
Surveying the composition and consequent labor policy of the NLRB from the Truman through the Bush administrations, Gross concludes that the inconsistent policy statements introduced by Taft-Harley have created a statutory hook upon which Republican-appointed Boards can hang their proemployer labor policy to the detriment of unions. The implementation of such a policy can be attributed in large part to employers' concerted manipulation of the political system (pp. 216, 235, 239), resulting in a backlogged Board lacking remedial powers (pp. 179, 253, 284), rampant union busting by employers (p. 270), and the prioritization of managerial prerogatives and property rights over labor-management codetermination (pp. 280-81).

Gross's most stinging critique is that the NLRB's spare remedial powers provide no deterrent to corporations intent on preventing unionization. For example, the usual remedy applied against an employer who commits a ULP is a "cease-and-desist order enjoining future violations." Gross calls the employer's cost of committing a ULP "a small investment with a high payoff," since by the time the employer has exhausted all of the available judicial appeals, "a union's majority may have been lost, its supporters demoralized, and its bargaining power weakened to the point where any contract it might be able to secure would be no better than what the employer was prepared to give without a union" (p. 186-87). ${ }^{15}$ Gross applauds the attempt by the McCulloch Board of the Kennedy-Johnson administrations to put some bite into Board remedies, ${ }^{16}$ but these proposals died in Congress (p. 183) and were never resurrected by the Nixon administration's Board (pp. 224-25).

The Board's effectiveness was further eroded when the Reagan and Bush administrations pursued what Gross calls "a deliberate attempt to have the agency wither under the weight of an unprecedented and ever-growing backlog" (p. 253). During the Reagan administration, the number of unfair labor practice cases decided by the Board dropped forty percent from 1982 to 1983, while the number of undecided unfair labor practice cases rose by over seventy-five percent from 1983 to 1984 (p. 253). This backlog was aggravated by the "failure of both Republican presidents to make timely appointments to the Board" (pp. 266-67), resulting in a Board that had its full complement of five members only thirty-eight percent of the time during the Reagan-Bush era.

Gross is right to criticize this deliberate policy of inaction during the Reagan and Bush administrations. By understaffing the Board and allowing thousands of unfair labor practice complaints to go unheard each year, these

14. Note, supra note 8 , at 531 .

15. See id. ("[A] cease-and-desist order enjoining fulure volations. . is verued by many employers and consultants as a mere 'slap on the wrist."'); see also GEOGHEGA.', supra note 7, at 253-5.4

16. Proposals included adding six percent interest to back pay awards. imposing tnple back pay awards against employers who intentionally or repeatedly violated the $A c t$, allowing nonemployec union organizers access to plants where elections had been set aside because of employer misconduct, and ordening employers who refused to bargain with a union to reimburse employees for the loss of wages and benefits employees would have received had the employer bargained in good fauth (pp. 181-82, 187) 
administrations wrongly eroded the effectiveness of the NLRA. By ignoring complaints, these Boards consciously disregarded their duty in a deliberate subversion of the NLRA. For those workers whose rights under the Act were violated by employers and who became unfortunate statistics in this backlog, justice delayed was justice denied. This policy had profound effects upon the labor movement. ${ }^{17}$ Once workers realized that they could be fired for union activity and would not receive judicial redress for many years, the appeal of unionization predictably declined.

Beneath his criticism of the Taft-Hartley Act and its inconsistent application by the NLRB, there is a subtext to Gross's analysis. He expresses disdain for a political process that has resulted in pro-employer Boards from 1968 through 1992. He categorizes the Dotson Board of the Reagan administration as "far more intently and overtly politicized than any of its predecessors" (p. 270). His attacks also extend to the Supreme Court and Congress, which he accuses of dictating labor policy based on individual ideologies rather than "empirical evidence" (pp. 192-93, 276). His implicit conclusion is that employers, through their efforts at "climate creation," have easily manipulated the American political system (pp. 194, 203, 205, 211).

However, there is nothing inherent in the American political system that forecloses all legislation favorable to labor. After all, Congress passed the Wagner Act in 1935 and it was upheld by the Supreme Court. ${ }^{18}$ Even within the post-Taft-Hartley statutory framework, the Herzog Board of the Truman administration and the McCulloch Board of the Kennedy-Johnson administrations advanced a labor philosophy favoring unionization and collective bargaining (pp. 92-94, 162). Some of the blame for recent failures lies with the labor movement. Gross acknowledges that "organized labor has been guilty over the years of following an unwise legislative strategy that produced several costly blunders" (p. 279). These blunders included an uncompromising demand for a complete repeal of Taft-Hartley after Truman's election in 1948. The AFL rejected many favorable amendments as alternatives $^{19}$ and, in an act of "self-defeating stubbornness," refused to

17. See, e.g., David L. Gregory, The Right to Unionize in the United States, Canada, and Mexico: A Comparative Assessment, 10 HoFSTRA LAB. L.J. 537, 541 (1993) ("Certainly the Reagan and Bush cra, reflecting the many pathologies of the 1980's, fueled and endorsed an overtly anti-labor environment. ... It became perniciously fashionable for ownership to ... fire employees who wished to organize with ruthless, cold abandon.").

18. See NLRB v. Jones \& Laughlin Steel, 301 U.S. 1 (1937).

19. Proposed amendments included loosening the closed shop prohibition, permitting striking employees to vote in representation elections even if they were not entitled to reinstatement, increasing the statute of limitations for filing charges with the NLRB from six months to one year, repealing the mandatory injunction clause of $\S 10(1)$, and deleting the statement in $\S 7$ of the Act explaining an 
coordinate its legislative activities with the $\mathrm{CIO}$ (p. 46-47). In 1978, despite the presence of a Democratic President and Congress, the AFL-CIO saw its highly coveted comprehensive labor law reform bill die at the hands of a Senate filibuster motivated by an aggressive corporate lobbying campaign (pp. 237-39). In 1994, again with a Democratic administration and Congress in power, the labor movement could not muster enough support to pass a bill that would have eliminated an employer's right to replace permanently striking workers. ${ }^{20}$ Similarly, labor interests could not block the passage of North American Free Trade Agreement (NAFTA), and were unable to unseat members of Congress who had voted for it, despite threats to do so."

Gross reserves the bulk of his criticism for business groups whose coordinated efforts enabled them to ensconce their labor relations philosophy as the one accepted by the NLRB, the courts, and Congress (pp. 203, 207. 235-36, 239). He criticizes corporate campaigns directed at creating an antiunion public perception (p. 208). ${ }^{22}$ These campaigns were accompanied by aggressive corporate lobbying that paid big political dividends, including the Ervin Committee hearings of 1968 designed covertly to discredit the prolabor Kennedy-Johnson Board and the defeat of the 1977 Labor Law Reform Bill (pp. 209-14,239). Corporate management, however, cannot take sole credit for these "successes." Labor unions have also contributed to a hostile public opinion. A prominent example is the Teamsters, whose ties to the Mafia and willingness to resort to thuggery not only helped cultivate an antilabor public sentiment, but also resulted in a suit brought by the Department of Justice."

Gross looks upon corporate manipulation of politics and public perception with disgust. He blames corporate America's success in enacting its legislative agenda for governmental "tyranny" in which "people exist for the economy" instead of "the economy exist[ing] for the people" (p. 286). However, he fails to acknowledge that it has been the effective use of the political process by corporate interests, which has gone largely unmatched by labor, that has resulted in the implementation of the probusiness labor policy with which he

employee's right to refrain from uniontzation and collectue barganning (p 54) See 29 U S C \$\$ 157 . 160(1) (1994).

20. See Asra Q. Nomani, Senate Ban on Permanem Replucement of Sinters Is Sralled in Labor Defeat, WALL ST. J., July 13, 1994, at A2.

21. See Asra Q. Nomani, Empry Threats: Labor Unsons Vowed ro Brnng Down Pro.Nafiu Polutucusts. It Didn't Happen, WALL ST. J., Oct. 28, 1994, at Rll ("The labor movement's threal to dethrone Nafta backers last year has ended up looking hollow;").

22. Hill \& Knowiton, the world's largest public relations firm. was hred b) a consortium of 40 employer groups known as the Labor Law Reform Group. It advised the Group to keep a low protile for fear that if the partisan corporate interests of the LLRG were revealed. public opinton would tum aganst it. Hill \& Knowiton then engaged in a broad-based campangn to disseminate information about the dangers of unions (pp. 204-09).

23. See GeOGHEGAN, supra note 7. at 137-38. 144. 156-58. see also Franh Suoboda. Teumsters Leader Loses Key Votes to Hoffa, WASH. POST. July 17, 1996. at D2 (discussıng suıt brought by Justice Department against Teamsters and resulting setlement): Frank Swoboda. Tuming Poun for Teamsters? Race to Head Union a Test of Reforms, WASH. POST. July 14. 1996. al HI (discussing "devil's pact" between Teamsters Union and organized crime). 
disagrees. Although business interests possess a great deal of money, the AFLCIO also has significant resources upon which it can draw to exert political influence. ${ }^{24}$ To survive, the labor movement must match the effectiveness of business interests in delivering its message to the public and influencing the political process. ${ }^{25}$ John Sweeney, the new President of the AFL-CIO, has committed his organization to financing the largest political grass-roots and media campaign by organized labor in a generation. ${ }^{26}$ In so doing, Sweeney is adopting a more pragmatic political strategy than his predecessor. ${ }^{27}$ This pragmatic, aggressive political approach could enable labor advocates to win over the majority of Americans who fall within the broadly defined working class. With reinvigorated leadership and a renewed dedication to politics, the AFL-CIO has the ability to advance its labor policy within the political system Gross has grown to mistrust. ${ }^{28}$

Gross believes that employees should participate in workplace decisions, and that all workplace issues should be mandatory subjects of bargaining (pp. 281,285 ). He believes that unfair labor practices should be vigorously policed, and that employees injured by them should have recourse to remedies that carry real force (p. 284). However, Gross must acknowledge that labor is as responsible for the current legal environment as is corporate management. Labor's best hope is to use effectively its resources to achieve substantive reforms. With a reinvigorated AFL-CIO, the labor movement is poised to use its money and power to reverse its forty-year decline and to take steps toward achieving what Gross would consider true industrial democracy.

-Charles T. Kimmett

24. See Swoboda \& Hamilton, supra note 9 ("The AFL-ClO gets more than $\$ 65$ million a year in ducs and has cash reserves of more than $\$ 55$ million. ... [T] he AFL-CIO will also benefit from the contribution of skilled political operatives detailed from individual unions to work in campaigns.").

25. To a certain extent, labor is doing so already. See, e.g., Nomani \& Rose, supra note 11 (discussing Sweeney's plan to create political training center to train campaign organizers and managers).

26. See Swoboda \& Edsall, supra note 11.

27. For example, although under Kirkland AFL-ClO union affiliates had vowed to "bring down" politicians who had voted for NAFTA, Sweeney has since dedicated millions of dollars to the reelection of President Clinton, an ardent NAFTA supporter. See Swoboda \& Hamilton, supra note 9.

28. Although Sweeney's election represents a significant step toward a reinvigoration of labor, other developments in the labor arena have not been as encouraging. In 1991, the Teamsters, under pressure from the Department of Justice, agreed to hold a national election to choose its leader. See GeOGHEGAN, supra note 7, at 158. The result was the election of a reform party candidate, Ron Carey. See Frank Swoboda, Hoffa Forces Disrupt Teamsters Convention, WASH. POST, July 16, 1996, at C1. Despite the fact Carcy has eliminated much of the corruption within the Teamsters organization, it appears as though he will be defeated in the November 1996 election by James P. Hoffa, an "old guard" Teamster seeking to take charge of the union once run by his father. See Glenn Burkins, Teamsters Chief Carey Loses Straw Poll of Delegates to Rival Candidate Hoffa, WALL ST. J., July 19, 1996, at A14. The prospect of the Teamsters being nu by another Jimmy Hoffa is unlikely to assuage existing public concern about union abuses. 